\title{
ANALISIS SHARE SEKTOR PERIKANAN SEBELUM DAN SESUDAH PENERAPAN KEBIJAKAN BLUE ECONOMY SERTA PENGARUH VARIABEL LAINNYA DI INDONESIA TAHUN 1990-2018
}

\author{
(Analysis of Share in The Fishery Sector Before and After Implementation of The Blue \\ Economy Policy and The Other Variables Affect It in Indonesia, 1990-2018)
}

\author{
Larasati Widyaningrum ${ }^{1}$, Atik Maratis Suhartini² \\ Politeknik Statistika STIS ${ }^{1}$ \\ Politeknik Statistika STIS² \\ Jl. Otto Iskandardinata 64C Jakarta Timur \\ E-mail: 16.9233@stis.ac.id
}

\begin{abstract}
ABSTRAK
Indonesia telah menerapkan pengembangan ekonomi kelautan dan perikanan yang berkelanjutan dengan model blue economy, sebagai upaya dalam memajukan berbagai aspek kegiatan perekonomian. Meningkatnya share sektor perikanan Indonesia dengan peningkatan yang cukup besar terjadi sejak diterapkannya kebijakan blue economy. Artinya, blue economy mengakibatkan sektor perikanan memiliki share terhadap perekonomian nasional yang semakin besar. Peningkatan share ini merupakan hal positif bagi perekonomian, tetapi di sisi lain keberlanjutan dari share sektor perikanan ini harus diperhatikan mengingat masih tingginya eksploitasi perikanan yang terus meningkat. Penelitian ini bertujuan untuk menganalisis share sektor perikanan sebelum dan sesudah diberlakukannya blue economy serta pengaruh ekspor dan impor hasil perikanan, hasil tangkapan per satuan upaya (CPUE), nelayan, dan armada terhadap share sektor perikanan, baik jangka panjang maupun jangka pendek. Metode analisis yang digunakan adalah Error Correction Mechanism (ECM). Hasil penelitian menjelaskan kebijakan blue economy mampu meningkatkan share sektor perikanan terhadap perekonomian dalam jangka pendek, tetapi tidak dalam jangka panjang. Artinya, blue economy penting dan bagus untuk diterapkan dalam jangka pendek serta harus selalu dievaluasi dan diperbaiki secara rutin supaya dalam jangka panjang akan memberikan pengaruh positif dalam meningkatkan share sektor perikanan. Selain itu, ekspor berpengaruh positif dan signifikan dalam jangka panjang, sedangkan CPUE, nelayan, dan armada berpengaruh negatif dan signifikan dalam jangka panjang. Impor berpengaruh negatif dan signifikan dalam jangka panjang maupun jangka pendek. Sehingga dalam meningkatkan share sektor perikanan, selain memperhatikan variabel-variabel yang terkait langsung, juga harus memperhatikan keberlanjutan dari kinerja sektor tersebut di masa mendatang, salah satunya dengan menerapkan kebijakan blue economy yang dilakukan dengan evaluasi dan perbaikan secara rutin.
\end{abstract}

Kata kunci: share sektor perikanan, blue economy, MSY, ECM

\begin{abstract}
Indonesia has implemented sustainable marine and fisheries economic development using blue economy model, as an effort to develop economic activity. There was an increase in fisheries sector share by large amount increase since the blue economy policy implementation. It means implementation of blue economy policy resulted more larger share of fisheries sector to national economy. Besides that, sustainability of this fisheries sector share must be considered because of continued fisheries exploitation. This study aims to analyze share of fisheries sector before and after implementation of blue economy policy, also analyze effect of exports and imports of fishery products, catch per unit effort (CPUE), fishermen and fleets on share of fisheries sector, both long and short term by Error Correction Mechanism (ECM) Alanysis. The results explain that blue economy policy is able to increase share of fisheries sector in short term, but not in the long term. It means that blue economy important to be implemented in the short term and must always be evaluated and corrected regularly so that in the long term it will have positive effect in increasing share of fisheries sector. In addition, exports have positive and significant effect to increase share of fisheries sector in the long term, while CPUE, fishermen and fleets have negative and significant effect in the long term. Imports have negative and significant effect in the long and short term. So that in increasing share of fisheries sector, in addition to paying attention directly related variables as blue economy policy, ekspor, impor, cpue,
\end{abstract}


fishermen, fleets, also pay attention to the sustainability of this sector performance. One of them is implementing blue economy policy carried out with regular evaluation and improvement routinely.

Keywords: share of the fishery sector, blue economy, MSY, ECM

\section{PENDAHULUAN}

APEC sebagai forum kerja sama negara-negara di Asia-Pasifik telah menerapkan pengembangan ekonomi kelautan dan perikanan yang berkelanjutan dengan model blue economy, sebagai salah satu upaya dalam memajukan berbagai aspek kegiatan perekonomian. Indonesia sebagai salah satu anggota APEC yang memiliki luas wilayah perairan sebesar 70 persen dari total luas wilayah, menunjukkan besarnya potensi perikanan di Indonesia. Bahkan sejak penerapan blue economy tahun 2004, neraca perdagangan hasil perikanan Indonesia mengalami peningkatan surplus dengan rata-rata 8,23 persen dibandingkan tahun sebelumnya yang cenderung stagnan (lihat Gambar 1). Seperti konsep dari blue economy itu sendiri yang mengutamakan peningkatan hasil perikanan dengan memperhitungkan keberlanjutan produksi perikanan itu sendiri. Setidaknya eksploitasi perikanan tanpa memperhatikan keberlanjutan produksinya bisa dikurangi sehingga masih menjamin keberlanjutan produksi perikanan di masa mendatang.

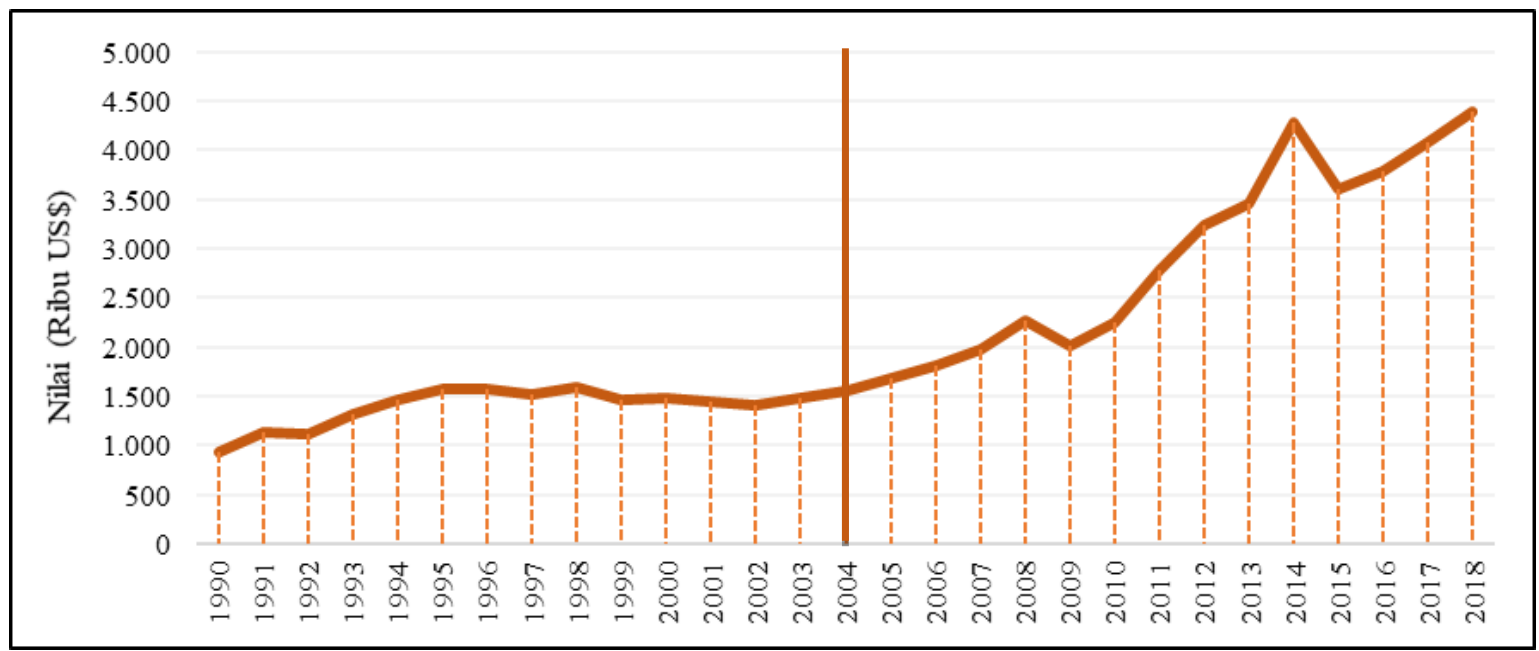

Sumber : KKP RI dan Statistik Sumber Daya Laut dan Pesisir, sudah diolah

Gambar 1. Neraca Perdagangan Hasil Perikanan Indonesia Tahun 1990-2018 (US \$)

Gambar 1 di atas menggambarkan meningkatnya share sektor perikanan dengan peningkatan yang cukup besar sejak diterapkannya kebijakan b/ue economy. Artinya sejak diberlakukannya kebijakan b/ue economy, sektor perikanan mengalami peningkatan pendapatan yang cukup tinggi sehingga memiliki sumbangan terhadap perekonomian nasional yang semakin besar juga. Di satu sisi peningkatan share ini merupakan hal yang positif bagi perekonomian, tapi di sisi lain keberlanjutan dari share sektor perikanan ini juga harus diperhatikan mengingat masih tingginya eksploitasi perikanan yang terus meningkat (KKP RI, 2018). Schaefer (1957) menuliskan konsep model pertumbuhan biologis yaitu menjaga keseimbangan biologi dari sumber daya ikan agar dapat dimanfaatkan secara maksimum dalam jangka waktu yang panjang. Konsep ini jika dilaksanakan akan menjamin keberlanjutan share sektor perikanan dalam perekonomian melalui kebijakan blue economy (Anjani, 2018). Berdasarkan penelitian oleh I Nyoman R, Erlania, dan Joni H (2015), penerapan kebijakan blue economy akan berjalan optimal apabila didukung oleh tersedianya teknologi dan peningkatan SDM. Selain itu, penelitian oleh Coro G, Large S, Magliozzi C, dan Pagano P (2016) tentang "Analysing and Forecasting Fisheries Time Series: Purse Seine in Indian Ocean As a Case Study" menjelaskan bahwa share dari sektor perikanan dipengaruhi oleh faktor mikroekonomi dan makroekonomi. 
Penelitian ini bertujuan untuk menganalisis share sektor perikanan sebelum dan setelah diberlakukannya kebijakan blue economy serta pengaruh ekspor dan impor hasil perikanan, hasil tangkapan per satuan upaya (CPUE), nelayan, dan armada terhadap share sektor perikanan, baik jangka panjang maupun jangka pendek.

\section{METODE}

\section{Potensi Sumber Daya Ikan (SDI) dalam Konsep Blue Economy}

Schaefer Gordon (1957) menerangkan bahwa SDI bersifat open access sehingga batas tanggung jawab dalam pengelolaan SDI menjadi tidak jelas, yang berdampak pada eksploitasi atau tangkap lebih (overfishing). Hartwick dan Olewiler (1998) menjelaskan fungsi pertumbuhan biologis ikan dalam jangka pendek. Berdasarkan gambar 2, tingkat pertumbuhan ikan terus meningkat dengan berkembangnya persediaan ikan hingga mencapai titik maksimum, kemudian akan menurun. Penurunan ini terjadi karena adanya jumlah maksimum yang hanya dapat ditampung oleh lingkungan.

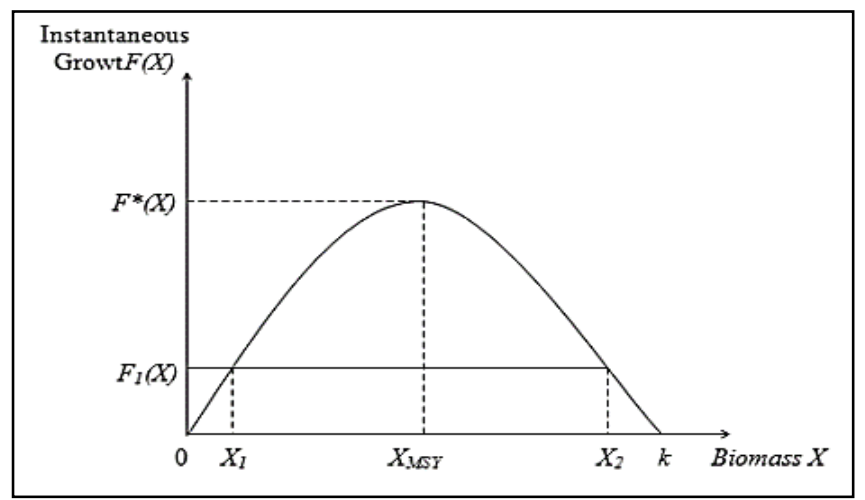

Sumber : Hartwick \& Olewiler, 1998

Gambar 2. Kurva dari Fungsi Pertumbuhan Logistik Perikanan

\section{Pembangunan Sektor Perikanan}

Berdasarkan Keputusan Menteri Kelautan dan Perikanan No.18/Men/2002, permasalahan dalam pembangunan perikanan dan kelautan diklasifikasikan menjadi dua tingkatan yaitu:

a. Mikro-teknis, permasalahan mengenai kondisi internal pembangunan di sektor perikanan, contohnya kemiskinan nelayan tinggi, rendahnya produktivitas, gejala tangkap lebih, rendahnya kemampuan pengolahan, lemahnya pemasaran dan pengembangan teknologi.

b. Makro-struktural, permasalahan dari faktor eksternal seperti ekonomi-makro, politik, hukum, kebijakan, dan kelembagaan. Contohnya sistem hukum dan kelembagaan perikanan yang lemah serta kelemahan kebijakan perikanan yang mendasar.

\section{Share Sektor Perikanan}

Menurut Badan Pusat Statistik (BPS) RI, salah satu indikator untuk mengetahui kondisi ekonomi suatu negara dalam suatu periode adalah Produk Domestik Bruto (PDB). PDB merupakan jumlah nilai tambah dari seluruh unit usaha dalam suatu negara tertentu. Penghitungan share sektor perikanan dalam perekonomian Indonesia dirumuskan sebagai berikut:

$$
(\text { Share })_{t}=\frac{(\text { PDBsektor })_{t}}{(\text { PDBnasional })_{t}}
$$

dimana:

(Share $)_{t} \quad=$ Share Sektor Perikanan pada tahun ke-t

$(\text { PDBsektor })_{t}=$ PDB Sektor Perikanan pada tahun ke-t 
$(\text { PDBnasional })_{t}=$ PDB Indonesia seluruh sektor pada tahun ke-t

\section{Teori Perdagangan Internasional}

Ada dua teori klasik yang menjelaskan mengenai perdagangan internasional, yaitu:

a. Teori Keunggulan Mutlak (Absolut Advantage) oleh Adam Smith

Suatu negara memperoleh keunggulan mutlak karena negara tersebut dapat memproduksi barang/jasa yang lebih murah dan efisien dibandingkan negara lain, yang disebabkan oleh produktivitas yang lebih tinggi.

b. Teori Keunggulan Komparatif (Comparative Advantage) oleh David Ricardo

Negara yang produksinya kurang efisien masih dapat melakukan perdagangan internasional, yaitu mengekspor komoditas dengan kelemahan absolut lebih kecil dan mengimpor komoditas dengan kelemahan absolut lebih besar. Hukum ini yang mendasari terjadinya ekspor dan impor.

Dalam "Fasilitasi Perdagangan, Kesiapan Indonesia Menghadapi Persaingan Global" oleh Pusat Penelitian, Badan Keahlian DPR RI, kegiatan ekspor dan impor dapat mengedepankan konsep pertumbuhan berkelanjutan baik jangka pendek maupun long term. Ekspor hasil perikanan adalah kegiatan memproduksi lalu mengirimkan komoditas perikanan ke negara lain guna memperoleh keuntungan. Impor hasil perikanan adalah kegiatan membeli komoditas perikanan dari negara lain untuk memenuhi kebutuhan dalam negeri yang tidak mampu diproduksi sendiri.

\section{Armada/Kapal Penangkap Ikan}

Kementerian PPN/Bappenas (2014) mengatakan bahwa armada menjadi input contro/ dalam pengelolaan perikanan berkelanjutan. Menurut KKP RI, armada adalah perahu/kapal yang langsung dipergunakan dalam operasi penangkapan ikan/binatang air lainnya/tanaman air. Klasifikasi armada dibagi menjadi dua, yaitu armada tradisional (perahu tanpa motor) dan armada modern (perahu/kapal motor). Tingginya jumlah penggunaan perahu tanpa motor mengartikan rendahnya kemampuan armada. Kemampuan armada yang rendah akan menyebabkan terjadinya illegal fishing (pencurian ikan) di berbagai perairan Indonesia (Rahim, 2013:105).

\section{Nelayan}

Menurut Kementerian PPN/Bappenas (2014), nelayan adalah input control (tenaga kerja) dalam pengelolaan perikanan berkelanjutan. Menurut KBBI $\mathrm{V}$, nelayan adalah orang yang mata pencahariannya menangkap ikan di laut. Hasil tangkapannya dimanfaatkan untuk mendukung ketahanan pangan, meningkatkan perekonomian nasional, dan meningkatkan devisa negara dalam sektor perikanan. Berdasarkan waktu jam kerjanya, nelayan terdiri atas tiga jenis yaitu:

a. Nelayan Penuh, adalah nelayan yang seluruh waktu kerjanya untuk menangkap ikan

b. Nelayan Sambilan Utama, adalah nelayan yang sebagian besar waktu kerjanya untuk menangkap ikan.

c. Nelayan Sambilan Tambahan, adalah nelayan yang sebagian kecil waktu kerjanya untuk menangkap ikan. 


\section{Metode}

Penelitian ini menggunakan data sekunder berupa data runtun waktu tahun 1990-2018 sehingga unit observasi berjumlah 29 tahun. Periode penelitian dirinci menjadi dua yaitu sebelum kebijakan blue economy (1990-2003) dan setelah kebijakan blue economy (2004-2018).

Tabel 1. Variabel Penelitian

\begin{tabular}{|c|c|c|}
\hline Variabel & Data & Sumber \\
\hline $\begin{array}{l}\text { Share Sektor } \\
\text { Perikanan }\end{array}$ & $\begin{array}{l}\text { Rasio PDB Sektor Perikanan ADHK } \\
2010 \text { terhadap PDB Nasional ADHK } \\
2010 \text { tahun 1990-2018 (persen) }\end{array}$ & $\begin{array}{l}\text { World Development Indicators (WDI) } \\
\text { serta Publikasi Statistik Sumber Daya } \\
\text { Laut dan Pesisir Badan Pusat Statistik } \\
\text { (BPS) }\end{array}$ \\
\hline Ekspor SDI & $\begin{array}{l}\text { Nilai Ekspor Sumber Daya Ikan tahun } \\
\text { 1990-2018 (juta US\$) }\end{array}$ & $\begin{array}{l}\text { Food and Agriculture Organiation (FAO) } \\
\text { dan Dirjen Penguatan Daya Saing } \\
\text { Kementerian Kelautan dan Perikanan RI }\end{array}$ \\
\hline Impor SDI & $\begin{array}{l}\text { Nilai Impor Sumber Daya Ikan tahun } \\
\text { 1990-2018 (juta US\$) }\end{array}$ & $\begin{array}{l}\text { Food and Agriculture Organiation (FAO) } \\
\text { dan Dirjen Penguatan Daya Saing } \\
\text { Kementerian Kelautan dan Perikanan RI }\end{array}$ \\
\hline \multirow{3}{*}{$\begin{array}{l}\text { Hasil } \\
\text { Tangkapan per } \\
\text { Satuan Upaya }\end{array}$} & \multicolumn{2}{|c|}{ CPUE (Catch Per Unit Effort) tahun 1990-2018 (kg/trip) } \\
\hline & $\begin{array}{l}\text { a) Volume Produksi Perikanan } \\
\text { Tangkap tahun } 1990-2018(\mathrm{~kg})\end{array}$ & $\begin{array}{l}\text { Dirjen Perikanan Tangkap Ke } \\
\text { Kelautan dan Perikanan RI }\end{array}$ \\
\hline & $\begin{array}{l}\text { b) Jumlah Alat Tangkap Perikanan } \\
\text { Tangkap tahun 1990-2018 (unit) }\end{array}$ & $\begin{array}{l}\text { Dirjen Perikanan Tangkap Kementerian } \\
\text { Kelautan dan Perikanan RI }\end{array}$ \\
\hline rikanan & $\begin{array}{l}\text { Jumlah Nelayan Perikanan Tangkap } \\
\text { tahun 1990-2018 (orang) }\end{array}$ & $\begin{array}{l}\text { Dirjen Perikanan Tangkap Kementerian } \\
\text { Kelautan dan Perikanan RI }\end{array}$ \\
\hline $\begin{array}{l}\text { Teknologi } \\
\text { Perikanan }\end{array}$ & $\begin{array}{l}\text { Jumlah Armada Perikanan Tangkap } \\
\text { tahun 1990-2018 (unit) }\end{array}$ & $\begin{array}{l}\text { DIrjen Perikanan Tangkap Kementerian } \\
\text { Kelautan dan Perikanan RI }\end{array}$ \\
\hline
\end{tabular}

\section{Metode Analisis Data}

Analisis inferensia dalam penelitian ini menggunakan analisis data runtun waktu dengan model Error Correction Mechanism (ECM). Tujuannya untuk mengetahui pengaruh ekspor dan impor perikanan, hasil tangkapan ikan per satuan upaya (CPUE), nelayan, dan armada terhadap share sektor perikanan, baik jangka panjang maupun jangka pendek.

Pertama, variabel yang sudah ditransformasi perlu melakukan uji stasioneritas pada level. Hipotesis uji Augmented Dickey Fuller (ADF):

$H_{0}: \delta=0$ (data terdapat akar unit atau data tidak stasioner pada level)

$H_{1}: \delta<0$ (data tidak terdapat akar unit atau data stasioner pada level)

Apabila $p$-value $>0,05$ maka keputusannya gagal tolak $H_{0}$, artinya data mengandung akar unit atau tidak stasioner pada level. Maka, selanjutnya adalah memastikan semua variabel harus stasioner pada difference yang sama agar ECM dapat dilanjutkan.

Kedua, pemodelan jangka panjang dengan metode estimasi OLS. Hasil regresi variabelvariabel bebas dengan variabel tak bebas membentuk persamaan jangka panjang sebagai berikut:

$$
\begin{aligned}
\text { PERANAN }_{t}= & \beta_{0}+\beta_{1} \text { LNEXPOR }_{t}+\beta_{2} \text { LNIMPOR }_{t}+\beta_{3} \text { LNCPUE }_{t}+\beta_{4} \text { LNNELAYAN }_{t}+ \\
& \beta_{5} \text { LNARMADA }_{t}+\beta_{6} \text { DUM }+u_{t}
\end{aligned}
$$

dimana:

PERANAN = share sektor perikanan terhadap nasional

LNEXPOR = nilai ekspor hasil perikanan Indonesia 


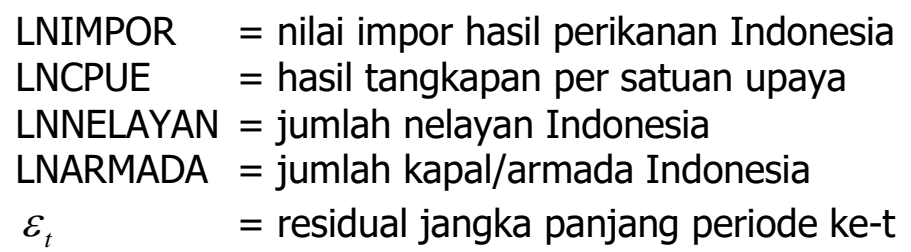

Setelah terbentuk persamaan jangka panjang, selanjutnya uji kointegrasi. Pengujian ini dilakukan melalui uji stasioneritas pada residual persamaan jangka panjang. Dengan hipotesis uji ADF, apabila $p$-value $<0,05$ maka keputusannya adalah cukup bukti untuk menolak $H_{0}$, artinya residual dari persamaan jangka panjang tidak mengandung akar unit atau stasioner. Hal tersebut menunjukkan adanya kointegrasi atau hubungan keseimbangan jangka panjang.

Ketiga, melakukan pemodelan ECM (persamaan jangka pendek), yang meregresikan semua variabel stasioner pada first difference dengan menambahkan first-lag dari residual persamaan jangka panjang. Persamaan jangka pendek yang terbentuk sebagai berikut:

$$
\begin{aligned}
& \triangle P E R \hat{A N A N} t_{t}=\alpha_{0}+\alpha_{1} \Delta \text { LNEXPOR }_{t}+\alpha_{2} \Delta \text { LNIMPOR }_{t}+\alpha_{3} \Delta \text { LNCPUE }_{t}+\alpha_{4} \Delta L N N E L A Y A N_{t} \\
& +\alpha_{5} \Delta L N A R M A D A_{t}+\alpha_{6} D U M+\alpha_{7} \widehat{\varepsilon}_{t-1}+e_{t}
\end{aligned}
$$

dimana:

$$
\begin{array}{ll}
\Delta & =\text { selisih antara tahun } t \text { dengan tahun } t-1 \text { (first difference) } \\
\widehat{\varepsilon}_{t-1} & =\text { Error Correction Term (ECT) } \\
e_{t} & =\text { residual jangka pendek periode ke-t }
\end{array}
$$

Hal penting dalam persamaan jangka pendek ini adalah koefisien dari first-lag residual $\widehat{\varepsilon}_{t-1}$ bertanda negatif. Sehingga tanda koefisien $a_{7}$ negatif. First-lag residual $\widehat{\varepsilon}_{t-1}$ ini merupakan selisih dari data $Y$ periode $t$ dengan nilai prediksi y periode $t-1$. Niai prediksi ini merupakan nilai y yang dipengaruhi oleh variable $x$. Sehingga selisih y periode $t$ dan nilai prediksi y yang dipengaruhi variable $\mathrm{x}$ periode $\mathrm{t}-1$, memiliki makna ketika ada shock pada variable $\mathrm{x}$ maka data y akan menyesuaikan nilainya hingga pengaruh shock tersebut hilang untuk menuju kondisi keseimbangannya di jangka panjang.

Selanjutnya, melakukan pengujian hipotesis statistik (uji simultan, uji parsial, dan koefisien determinasi) serta pengujian asumsi klasik pada persamaan jangka pendek. Dalam penelitian ini, uji asumsi klasik terdiri atas uji normalitas (uji Jarque Bera), uji homoskedastisitas (uji Glejser), uji nonautokorelasi (uji Durbin-Watson dan uji Lagrange-Multiplier), dan uji nonmultikolinieritas (nilai VIF).

\section{HASIL DAN PEMBAHASAN}

\section{Uji Stasioneritas}

Uji stasineritas data dimaksudkan agar tidak menimbulkan spurious regression. Variabel yang diujikan yaitu share sektor perikanan, log nilai ekspor, log nilai impor, log CPUE, log nelayan, dan log armada, dan dummy blue economy. Berdasarkan hasil uji ADF, nilai probabilitas semua variabel yaitu lebih dari sama dengan $\alpha=0,05$ maka keputusan gagal tolak $H_{0}$, artinya data mengandung akar unit atau tidak stasioner pada level. Oleh sebab itu, perlu melakukan uji stasioner pada first difference.

Berdasarkan uji stasioneritas pada first difference, nilai probabilitas dari semua variabel yaitu kurang dari $\alpha=0,05$ maka keputusannya adalah tolak $H_{0}$, artinya data tidak mengandung akar unit atau data stasioner pada first difference. Jadi, dapat melanjutkan pemodelan ECM.

\section{Uji Kointegrasi Model Jangka Panjang}


Uji kointegrasi digunakan untuk melihat keseimbangan jangka panjang antara variabelvariabel bebas dengan variabel tak bebas. Uji kointegrasi dilakukan dengan uji stasioneritas residual dari persamaan jangka panjang. Nilai probabilitas dari uji kointegrasi ADF $(0,0044)$ lebih kecil dibandingkan tingkat signifikansi $(0,05)$, maka keputusan tolak $H_{0}$ artinya residual dari persamaan jangka panjang stasioner. Dengan tingkat signifikansi 5 persen, dapat disimpulkan adanya kointegrasi atau hubungan keseimbangan jangka panjang antar variabel penelitian.

Terpenuhinya uji kointegrasi artinya variabel-variabel dalam penelitian memiliki hubungan jangka panjang. Berikut adalah persamaan jangka panjang yang terbentuk:

$$
\begin{aligned}
\text { PERANANN }_{t}= & 22,3124^{*}+0,3659 \text { LNEXPOR }_{t}^{*}-0,2476 \text { LNIMPOR }_{t}^{*}-0,0593 \text { LNCPUE }_{t}^{*}- \\
& 0,7598 \text { LNNELAYAN }_{t}^{*}-0,7501 \text { LNARMADA }_{t}^{*}-0,0054 \text { DUM }+u_{t} \ldots \ldots \ldots \ldots \ldots . . .
\end{aligned}
$$

Keterangan: *) signifikan pada tingkat signifikansi 5 persen

Nilai prob F-statistik $(0,0000)$ kurang dari tingkat signifkansi $(0,05)$ artinya keputusan tolak $H_{0}$. Dengan tingkat signifikansi 5 persen, ada minimal satu variabel bebas dalam model yang memengaruhi share sektor perikanan dalam jangka panjang. Namun secara parsial, hanya ada lima variabel (nilai ekspor perikanan, nilai impor perikanan, CPUE, jumlah nelayan, dan jumlah armada) yang berpengaruh signifikan terhadap share sektor perikanan dalam jangka panjang.

Selain itu, model tersebut memiliki nilai Adjusted R-squared sebesar 0,8169 artinya 81,69 persen keragaman dari share sektor perikanan dapat dijelaskan oleh keragaman nilai ekspor perikanan, nilai impor perikanan, CPUE, jumlah nelayan, jumlah armada, dan dummy blue economy sedangkan 18,31 persen sisanya dijelaskan oleh variabel lain di luar model.

Dari persamaan 3, nilai ekspor perikanan memengaruhi share sektor perikanan secara positif dan signifikan. Kemudian, nilai impor perikanan, CPUE, jumlah nelayan, dan jumlah armada masing-masing memengaruhi share sektor perikanan secara negatif dan signifikan.

\section{Model Jangka Pendek (ECM)}

Selanjutnya adalah membentuk model jangka pendek untuk mengetahui besar koreksi ketidakseimbangan jangka pendek menuju keseimbangan jangka panjang. Nilai prob F-statistik $(0,0019)$ kurang dari tingkat signifikansi $(0,05)$ artinya keputusan tolak $H_{0}$. Dengan tingkat signifikansi 5 persen, ada minimal satu variabel bebas dalam model yang memengaruhi share sektor perikanan dalam jangka pendek. Namun secara parsial, hanya ada tiga variabel (nilai impor perikanan, dummy blue economy, dan variabel koreksi keseimbangan) yang berpengaruh signifikan terhadap share sektor perikanan dalam jangka pendek.

Selain itu, model tersebut memiliki nilai Adjusted R-squared sebesar 0,5163 artinya 51,63 persen keragaman dari share sektor perikanan dapat dijelaskan oleh keragaman nilai ekspor perikanan, nilai impor perikanan, CPUE, jumlah nelayan, jumlah armada, dummy blue economy, dan koreksi keseimbangan sedangkan 48,37 persen sisanya dijelaskan oleh variabel lain di luar model.

Berikut adalah persamaan dari model jangka pendek yang terbentuk:

$$
\begin{aligned}
& \triangle P E R \hat{A N A N}{ }_{t}=-0,0565+0,0424 \triangle \text { LNEXPOR }_{t}-0,1244 \triangle \text { LNIMPOR }_{t}^{*}-0,0482 \triangle \text { LNCPUE }_{t}- \\
& 0,2245 \Delta \text { LNNELAYAN }_{t}-0,1525 \Delta \text { LNARMADA }_{t}+0,1530 \text { DUM }^{*}-0,7869 E C T(-1)^{*} \\
& +e_{t}
\end{aligned}
$$

Keterangan: *) signifikan pada tingkat signifikansi 5 persen

Dari persamaan 5, setiap peningkatan 1 persen perubahan nilai impor perikanan akan menurunkan perubahan dari share sektor perikanan sebesar 0,1244 persen. Kemudian, penerapan kebijakan blue economy di Indonesia akan meningkatkan perubahan dari share sektor perikanan sebesar 0,0765 persen. Selain itu, diperoleh nilai ECT sebesar -0,7869. Dengan tingkat signifikansi 5 persen, ketidakseimbangan share sektor perikanan pada tahun sebelumnya akan terkoreksi 
sebesar 78,69 persen pada tahun berjalan dan akan terkoreksi sebesar 21,31 persen pada tahuntahun selanjutnya. Dengan kata lain, ketika terjadi shock pada salah satu variabel penjelas yang diobservasi, maka nilai share sektor perikanan yang dipengaruhi oleh variabel non-observasi (ECT) akan menyesuaikan dengan sendirinya sebesar 78,69 persen hingga pengaruh shock tersebut hilang untuk menuju keseimbangannya.

\section{Uji Normalitas}

Uji normalitas menggunakan uji Jarque Bera pada residual persamaan jangka pendek. Nilai probabilitas sebesar 0,7494 lebih besar dari 0,05 maka keputusannya adalah gagal tolak $H_{0}$. Dengan tingkat signifikansi 5 persen, memiliki cukup bukti untuk menyatakan bahwa residual model berdistribusi normal.

\section{Uji Homoskedastisitas}

Uji homoskedastisitas menggunakan uji Glejser pada residual persamaan jangka pendek. Nilai probabilitas Chi-Square sebesar 0,0565 lebih besar dari 0,05 maka keputusannya adalah gagal tolak $H_{0}$. Dengan tingkat signifikansi 5 persen, memiliki cukup bukti untuk menyatakan bahwa varians residual model konstan atau bersifat homoskedastisitas.

\section{Uji Nonautokorelasi}

Uji nonautokorelasi menggunakan uji Durbin-Watson pada residual persamaan jangka pendek. Nilai statistik Durbin-Watson, $\mathrm{D}=1,7961$. Dengan $\mathrm{k}=8$ dan $\alpha=0,05$ maka nilai $d_{L}=0,8263$ dan $d_{U}=2,1636$. Nilai $\mathrm{D}$ berada dalam selang $d_{L}<D<d_{U}$ keputusannya adalah tidak dapat disimpulkan. Oleh sebab itu, perlu dilanjutkan ke uji LM. Berdasarkan hasil uji LM, nilai probabilitas chi-squared sebesar 0,0739 lebih dari 0,05 maka keputusan adalah gagal tolak $H_{0}$. Dengan tingkat signifikansi 5 persen, memiliki cukup bukti bahwa residual model tidak berkorelasi dari waktu ke waktu atau bersifat nonautokorelasi.

\section{Uji Nonmultikolinieritas}

Cara mendeteksi ada tidaknya multikolinieritas yaitu dengan melihat nilai Variance Inflation Factor (VIF) pada variabel-variabel bebas persamaan jangka pendek. Hasil pengujian menunjukkan nilai VIF masing-masing variabel bebas kurang dari 10. Dengan tingkat signifikansi 5 persen, memiliki cukup bukti untuk menyatakan terjadi nonmultikolinieritas antara variabelvariabel bebas dalam model jangka pendek.

\section{Interpretasi}

Variabel ekspor perikanan memengaruhi share sektor perikanan secara positif dan signifikan, sedangkan variabel impor perikanan memengaruhi share sektor perikanan secara negatif dan signifikan. Keduanya sejalan dengan penelitian Lukman Adam (2013) dan Teori Pendekatan Pengeluaran yang menjelaskan bahwa meningkatnya ekspor perikanan atau menurunnya impor perikanan dengan asumsi PDB Indonesia konstan, maka akan menurunkan PDB sektor perikanan yang juga akan menurunkan share sektor perikanan.

Variabel hasil tangkapan per satuan upaya (CPUE) memengaruhi share sektor secara negatif. Hal tersebut mengartikan bahwa CPUE mengindikasikan ketika adanya penurunan eksploitasi artinya perikanan Indonesia menunjukkan keadaan yang membaik. Didukung dengan penelitian Zebua dan Ramli (2013), asumsikan upaya yang dilakukan adalah 1 trip. Maka, CPUE merupakan hasil tangkapan (produksi tangkap) dalam sekali trip. Volume produksi tangkap dan PDB Perikanan memiliki hubungan negatif. Hal ini tidak sesuai dengan hipotesis penelitian, disebabkan oleh volume produksi tangkap Indonesia yang tergolong rendah sehingga berpengaruh negatif 
terhadap share sektor perikanan (data WDI dan FAO). Rendahnya volume produksi tangkap Indonesia dikarenakan banyaknya illegal fishing oleh kapal asing maupun nelayan tanpa izin di beberapa perairan Indonesia.

Variabel nelayan memengaruhi share sektor perikanan secara negatif. Hal ini tidak sesuai dengan hipotesis penelitian. Namun, menurut Kementerian PPN/Bappenas (2014), keadaan tersebut disebabkan oleh kualitas nelayan dinilai masih relatif rendah atau mayoritas adalah nelayan kecil. Karena faktor tersebut, pendapatan yang diperoleh akan sangat kecil karena mereka hanya bergantung dari upah harian yang diperolehnya. Akhirnya, mereka akan mencari tambahan pendapatan di sektor lain atau beralih ke sektor yang lebih menguntungkan. Perpindahan sektor ini menjadi akibat dari susahnya bertahan hidup dalam ketidakpastian pendapatan tersebut. Selain itu, sesuai penelitian Kusumastanto (2008), walaupun jumlah nelayan banyak, hasil tangkapan yg diperolehnya makin berkurang, akibat dari banyaknya kapal asing di perairan Indonesia. Hal itu terjadi karena 60,09 persen alat tangkap nelayan Indonesia didominasi dengan alat tangkap sederhana (pancing dan jaring insang) dibandingkan kapal asing dengan alat tangkap yang dapat menangkap semua jenis ikan. Akibatnya dalam jangka panjang, stok ikan di laut akan terus berkurang, sehingga peranan sektor perikanan menurun karena tidak tercukupinya stok ikan sebagai sumber utama pendapatan.

Variabel armada memengaruhi share sektor perikanan secara negatif, sesuai dengan penelitian Rahim (2013). Keadaan ini tidak sesuai dengan hipotesis penelitian. Menurut KKP RI (2019), 90 persen armada Indonesia didominasi oleh kapal skala kecil atau kapal berbobot kurang dari $30 \mathrm{GT}$. Hal tersebut menjadi aspek mendasar yang memengaruhi lemahnya daya saing dan produktivitas sehingga nantinya akan menurukan share sektor perikanan.

Dalam jangka panjang, penerapan kebijakan blue economy di Indonesia mulai tahun 2004 memberikan pengaruh yang tidak signifikan. Namun, dalam jangka pendek, blue economy berpengaruh positif signifikan terhadap peranan sektor perikanan. Pada dasarnya, penerapan kebijakan tersebut bersifat nasional dan sebagai dasar untuk pelaksanaan di tingkat regional. Pada penerapannya, kebijakan tersebut dikembalikan kepada pemerintah masing-masing regional untuk berfokus pada tujuan kegiatan ekonomi yang dapat menghasilkan banyak keuntungan atau hanya sekedar melindungi hidup masyarakatnya. Ternyata menurut Direktur Senior Konservasi Internasional Indonesia (2018) dalam Global Landscapes Forum Blue Carbon Summit, beberapa diantaranya memilih subsistensi jangka pendek, artinya bahwa kegiatan ekonomi yang didasarkan pada kebijakan blue economy ini ada yang berfokus hanya sebagai pemenuhan kebutuhan hidup pribadi dari masyarakatnya, bukan pada aspek mencari keuntungan. Akibatnya, share sektor perikanan juga tidak menunjukkan peningkatannya.

\section{KESIMPULAN}

Berdasarkan hasil dan pembahasan penelitian ini, dapat disimpulkan bahwa kebijakan blue economy mampu meningkatkan share sektor perikanan terhadap perekonomian dalam jangka pendek, tetapi tidak dalam jangka panjang. Hal tersebut mengartikan bahwa blue economy penting dan bagus untuk diterapkan dalam jangka pendek serta harus selalu dievaluasi dan diperbaiki secara rutin supaya dalam jangka panjang akan memberikan pengaruh positif dalam meningkatkan share sektor perikanan. Selain itu, ekspor berpengaruh positif dan signifikan dalam jangka panjang, sedangkan $\mathrm{CPUE}$, nelayan, dan armada berpengaruh negatif dan signifikan dalam jangka panjang. Impor berpengaruh negatif dan signifikan dalam jangka panjang maupun jangka pendek. Sehingga untuk menjaga keberlanjutan peningkatan share sector perikanan selain memperhatikan variable variable yang terkait langsung, juga memperhatikan keberlanjutannya misalnya dengan menerapkan kebijakan blue economy dengan evaluasi dan pengembangan secara berkala.

\section{UCAPAN TERIMA KASIH}

Penulis mengucapkan terima kasih yang sebesar-besarnya kehadirat Allah SWT atas ijin dan ridhoNya, orang tua dengan segenap doa dan dukungan penuh, dosen pembimbing dan semua rekan yang terlibat baik langsung maupun tidak, Badan Pusat Statistik, KKP RI, dan lingkungan 
Politeknik Statistika STIS keseluruhan atas kesempatan dan kemudahan dalam keseluruhan proses penelitian.

\section{DAFTAR PUSTAKA}

Anjani, Adriana. (2018). Kerja Sama KKP RI-FAO dalam Implementasi Kebijakan Ekonomi Biru Indonesia dengan Studi Kasus The Lombok Blue Economy Implementation Program [Skripsi]. Bandung: Program Studi Ilmu Hubungan Internasional, Fakultas Ilmu Sosial dan Ilmu Politik Universitas Katolik Parahyangan.

Badan Pusat Statistik. (2018). Publikasi Statistik Sumber Daya Laut dan Pesisir 2018. Jakarta: Badan Pusat Statistik.

Coro, G., Large, S., Magliozzi, C., \& Pagano, P. (2016). Analysing and Forecasting Fisheries Time Series: Purse Seine in Indian Ocean as a Case Study. ICES Journal of Marine Science, 73 (10). 2552-2571.

Gujarati, Damodar N. \& Porter, Dawn C. (2009). Basic Econometrics Fifth Edition. New York: McGraw-Hill Inc.

Hartwick J.M and Nancy D. Olewiler, (1998). The Economics of Natural Resource Use Second Edition. Addison Wesley.

Juanda, Bambang \& Junaidi. (2012). Ekonometrika Deret Waktu. Bogor: Institut Pertanian Bogor (IPB) Press.

Kementerian Kelautan dan Perikanan. (2018). Publikasi Produktivitas Perikanan Indonesia. Jakarta: Kementerian Kelautan dan Perikanan.

Kementerian PPN/Bappenas. (2014). Kajian Strategi Pengelolaan Perikanan Berkelanjutan. Jakarta: Kementerian PPN/Bappenas.

Keputusan Menteri Kelautan dan Perikanan RI. (2002). Tentang Rencana Strategis Pembangunan Kelautan dan Perikanan Tahun 2002-2004. Keputusan Menteri Kelautan dan Perikanan No.18/Men/2002. KKP RI. Jakarta.

Kusumastanto, Tridoyo. (2008). Publikasi Kebijakan dan Strategi Peningkatan Daya Saing Produk Perikanan Indonesia. Jawa Barat: Pusat Kajian Sumberdaya Pesisir dan Lautan Institut Pertanian Bogor.

Radiarta, Nyoman., Erlania, \& Haryadi, Joni. (2015). Analisis Pengembangan Perikanan Budidaya Berbasis Ekonomi Biru Dengan Pendekatan Analytic Hierarchy Process (AHP). Jurnal Sosial Ekonomi Kelautan dan Perikanan KKP RI, 10 (1). 47-59.

Rahim, Abd. (2013). Estimated of Catches Production on Panel Data Econometrics Model Approach. Jurnal Ekonomi Pembangunan dan Pertanian Fakultas Ekonomi Universitas Negeri Makassar, 4 (1). 103-117.

Schaefer, MB. (1957). Some Considerations of Population Dynamics and Economics in Relation to The Management of The Commercial Marine Fisheries. Journal of Fisheries Research Board of Canada, 1(1):669-681.

Zebua, N.D. \& Ramli (2013). Analisis Pengaruh Jumlah Armada, Jumlah Nelayan, PDRB, dan Investasi terhadap Produksi Perikanan di Wilayah Nias (Analisis Data Panel). Jurnal Ekonomi dan Keuangan, 2(8). 463-474. 